\title{
Ijarah Procedure Modeling Using Petri Net (A case study in "KSPPS BMT Bima" Magelang)
}

\author{
Sarngadi Palgunadi Yohanes and Dania Faaskarini
}

\begin{abstract}
In this paper a Petri net model for ijarah procedure has been created. The procedure has been tested freely from soundness, liveness and boundedness. The ijarah procedure consists of six sub-procedures, there are the application sub-procedure, analysis sub-procedure, contract determination sub-procedure, disbursement sub-procedure, installment sub-procedure, and settlement sub-procedure. Application for ijarah simulation has been developed that can record the event log according to the position of the place and the transition of each customer. Simulation was conducted for 100 customers randomly. The result showed that there are 76 customers passed the application stage, 38 customers passed the analysis stage, 26 customers passed the contract determination stage and disbursement stage, 5 customers experiencing repayment issues, and 1 customer still has installments.
\end{abstract}

Index Terms_Ijarah, Petri net, Business process modeling

\section{INTRODUCTION}

Loan is the provision of money or bills that can be equated with that based on borrowing agreements between a bank and other parties who require the borrower to repay their debts after a certain period of time with interest [1]. Loan is one of the main activities of banking. The number of loans distributed by a bank will determine the profit of the bank. If the bank unable to distribute loan while there are a lot of funds collected from customers, it will be causing loss to the bank. [2]. Banks need to provide an assessment to the customers who apply for loan in order to obtain a belief that the customer is able to repay the loan received [3]. Therefore, banks need a loan delivery system so the loan activities may run smoothly [4].

Example of existing loan in the community is a multiservice ijarah. Ijarah is a contract of transfer of right or benefit of goods or services within a specific amount of time through payment of leases or wages, without being followed by the transfer of ownership of the goods themselves [5]. Multi-service financing is a financing provided by the sharia financial institutions to customers in order to obtain the benefits of a service [6].

A workflow can be used to represent business processes of ijarah delivery procedure [7]. One method that can be used to analyze workflow is Petri net. Petri net can be used to specify complex workflows. The Petri net structure can be used to find an error in a workflow [8]. Another advantage of Petri net is the

Manuscript received November 14, 2016.

Sarngadi Palgunadi Yohanes is with Informatics Department FMIPA Sebelas Maret University, Solo, Indonesia

Dania Faaskarini is with Informatics Department FMIPA Sebelas Maret University, Solo, Indonesia process that can be described graphically, has strong mathematical modeling, and has a lot of analytical techniques such as soundness, liveness, and boundedness [9].

This paper aims to model, as well as to implement, ijarah procedure using Petri net in one of the sharia financial institution in Indonesia ("KSPPS BMT Bima" Magelang)

\section{PETRI NET}

Petri net is a directed graph consists of place and transition that connected with arc [9]. Place represents the possible states or conditions, while the transition represents the events or actions. Place depicted as a circle while transition depicted as a square. Place may have one or more tokens to simulate the system. Token depicted as black dots. Transitions have the number of inputs as pre-condition and the number of outputs as post-condition. The number of tokens may change during the execution of the net.

Transitions are the active components of Petri net that change the state according to the following rule [8] :

1. A transition $t$ is enabled if each input place $\mathrm{p}$ of $\mathrm{t}$ contains at least one token.

2. An enabled transition may fire. If transition $\mathrm{t}$ fires, then $\mathrm{t}$ consumes one token from each input place $\mathrm{p}$ of $\mathrm{t}$ and produces one token for each output place $\mathrm{p}$ of $\mathrm{t}$.

\section{A. Petri Net Analysis Technique}

Analysis method in Petri net is described as follows.

a) Structural Analysis

The structural analysis of Petri net is based on the model structure in errors condition that often occur as follows [8] :

1. Has the input condition and output condition. When a Petri net model has no input condition it will cause obscurity when the task will begin and when has no output condition it will not contribute to the processing case that has been modeled.

2. There is no dead transitions which occurs when a task cannot be executed.

3. No deadlock occurs which when a task is stopped before the end condition is reached.

4. No livelock occurs which when there is routing repeated without end.

5. There is no task that should be done after the end condition is reached.

6. There is no token in the process after reaching the end condition.

b) Boundedness

A Petri net is bounded for each place $p$ when the number of 
tokens in $p$ restricted or in other words when the number of tokens in $p$ does not exceed the number of tokens in the source place [8].

\section{c) Liveness}

A Petri net $(P N, M)$ is live if for every reachable state $M^{\prime}$ and every transition $t$ there is a state $M^{\prime \prime}$ reachable from $M^{\prime}$ which enables transition $t$ [8], and it is possible to fire any transition of the net by some further firing sequence [9].

\section{d) Soundness}

A procedure modeled by Petri net is sound if for every state $M$ reachable from state $i$ there exists a firing sequence leading from state $M$ to state $o$, state $o$ is the only state reachable from state $i$ with at least one token in place $o$, and there are no dead transitions [8].

\section{B. Incidence Matrix}

The incidence matrix $A=\left[a_{i j}\right]$ is a $(n \times m)$ matrix for petri net with ${ }^{n}$ places and ${ }^{m}$ transitions defined as [10]

$$
a_{i j}=a_{i j}{ }^{+}-a_{i j}{ }^{-}
$$

Where,

$a_{i j}{ }^{+}=$weight of the arc from transition $j$ to its output place $i$

$a_{i j}{ }^{-}=$weight of the arc to transition $j$ from its input place $i$

\section{THE IJARAH PROCEDURE MODELLING}

Rules of the procedure are determined by ijarah process that occurs in "KSPPS-BMT Bima" Branch Office Ngluwar Magelang, Indonesia. The rules are developed to facilitate the modeling process of the procedure. The ijarah procedure consists of six sub-procedures, there are application sub-procedure, analysis sub-procedure, contract determination sub-procedure, disbursement sub-procedure, installment sub-procedure, and settlement sub-procedure that are executed sequentially.

\section{A. Rules for Application Sub-Procedure}

Ijarah application process is an ijarah request made by debtor. In this sub-procedure, the debtor requests an ijarah application through customer service. There are six application forms to be filled and prepared by the debtor, i.e. forms of member data, family data, financial data, ijarah application data, and files. Processing scheme for ijarah application sub-procedure is as follows :

1. The debtor requests for ijarah application

2. Customer service check if the debtor being customer or not, if not then the debtor should be registered as a customer first (complete member data form).

3. If the debtor has already been a customer then further to the next step.

4. Customer service check whether the ijarah application submitted is the first request of the customer or not.

5. If the first application then debtor fill the rest of the forms.

6. If not, debtor completes ijarah application data form, business data form as well as the files.

7. Customer service checks the completeness of the forms and files. If the forms are filled out and the required files have been completed then conducted next step, if not, the related form must be completed.

8. Once all of the forms have been completed, then the ijarah application sub-process is done.

\section{B. Rules for Ijarah Analysis Sub-Procedure}

At this sub-procedure, finance section conducting a survey to clarify the things that associated with the customer. Furthermore, the collected data is checked and analyzed to judge whether the debtor eligible to get credit or not. There are three forms to be filled by the surveyor (finance section), there are risk identification form, analysis of revenues and costs form, and questionnaire form. Processing scheme for ijarah analysis sub-procedure is as follows :

1. Officer conducts a survey.

2. Officer completes the forms of ijarah risk identification, analysis of revenues and costs, and questionnaire.

3. The financing section checks the data. If the data appropriate, then it can continue to the next process, if not then the data in the related form must be completed.

4. Then the financing section analyzes the survey result and the value of the collateral.

5. To obtain ijarah approval, customers get the value of the questionnaire at least $50 \%$ and the value of the collateral must be fulfilled in accordance with the standards established by management, otherwise, the ijarah agreement will be rejected.

6. Calculating the customer ability of installment. If the customer ability is not appropriate then the ijarah approval will be rejected.

7. Determining the amount of loan can be accepted based on the calculation of ability of installments.

\section{Rule for Contract Determination Sub-Procedure}

At contract determination sub-procedure, the debtor and the financial institutions agree to hold a financing agreement with the terms and conditions specified by financial institutions. At this stage, both parties agree to deciding matters related to financing, as well as matters described in the contract. Determination of the contract is described in clauses. Such clauses are grouped into preamble form, clause 1 to clause 4 , clause 6 to clause 9, and clause 5. Processing scheme for contract determination sub-procedure is as follows :

1. Officer completes preamble form, clause 1 to clause 4 , and clause 6 to clause 9 .

2. If data is complete and appropriate, then continue to the next process, if not then the related form must be completed and revised.

3. Officer completes collateral information form.

4. If data is complete and appropriate, then continue to the next process, if not then the related form must be completed and revised.

5. If there are more than one collateral then we need the addition of collateral, go back to point 3 .

6. If there is no addition of collateral needed, the process is done.

\section{Disbursement Sub-Procedure}

At this stage, debtor receives the amount oftz money according to the contract. Processing scheme for disbursement 
sub-procedure is as follows :

1. Customer fills disbursement form.

2. Officer checks the completeness of the data. If complete, the officer gives approval by signing the disbursement form.

3. Officer prepares the amount of money as stated in the contract.

4. Customer receives the money.

5. Ijarah disbursement process is done.

\section{E. Installment Sub-Procedure}

At this stage, debtor conducts installment payment in accordance with the contract. Processing scheme for installment sub-procedure is as follows :

1. Officer checks the installments record of the customer regularly or by customer request.

2. If the customer does not have the ability to continue the installment or if the collateral is lost then the customer is eligible to be in the "deletion of collateral" program.

3. Customer fills cash inflow form.

4. If the data is appropriate then the installment is received, if not then the customer must revise the data.

5. If the customer is late to pay installment then fine is added according to the contract. If the customer ignores, the billing charges is added according to the contract.

6. If the customer has another installment then go back to the menu points 3 .

7. If not then the installment process is done.

Processing scheme of fines payment and billing costs are similar to the installment scheme by eliminating point 5 .

\section{F. Settlement Sub-Procedure}

The settlement stage is the last process. At this stage, the collateral will be returned to the customer. Processing scheme for settlement sub-procedure is as follows :

1. Officer checks the installments record of the customer.
2. If customer still has another installment to be paid, customer has to pay installment previously, if not then the customer can conduct the return process of the collateral.

3. Officer prepares collateral return form.

4. Officer fills the collateral return form.

5. If appropriate, the collateral eligible to be returned.

6. Collateral returns process is done.

7. The ijarah process is done.

\section{PETRI Net MOdEL For IJARAH PROCEDURE}

From the rules that have been developed previously, Petri net models were developed for each sub-procedure using Woped editor. Petri net model for ijarah application sub-procedure is shown in Fig. 1 where there are 18 places and 15 transitions. Description of the model is shown in Table I.

TABLE I

Description of Places AND TRANSitions of PetRi Net Fig. 1

\begin{tabular}{ll}
\hline \hline Caption & Description \\
\hline $\mathrm{p} 1-\mathrm{t} 1$ & Apply for ijarah \\
$\mathrm{p} 2-\mathrm{t} 2$ & Check whether debtor is customer \\
$\mathrm{p} 3-\mathrm{t} 3$ & Register as a customer member \\
$\mathrm{p} 3-\mathrm{t} 4$ & Check whether first application \\
$\mathrm{p} 4-\mathrm{t} 5$ & Fill application forms part 1 \\
$\mathrm{p} 5-\mathrm{t} 6$ & Fill family data form \\
$\mathrm{p} 6-\mathrm{t} 7$ & Fill financial data forms \\
$\mathrm{p} 7-\mathrm{t} 8, \mathrm{p} 8-\mathrm{t} 8$ & Check data input \\
$\mathrm{p} 9-\mathrm{t} 9$ & Fill out data input \\
$\mathrm{p} 10-\mathrm{t} 10$ & Fill application forms part 2 \\
$\mathrm{p} 11-\mathrm{t} 11$ & Fill ijarah application form \\
$\mathrm{p} 12-\mathrm{t} 12$ & Fill business data form \\
$\mathrm{p} 13-\mathrm{t} 13$ & Fill files form \\
$\mathrm{p} 14-\mathrm{t} 14, \mathrm{p} 15-\mathrm{t} 14, \mathrm{p} 16-\mathrm{t} 14$ & Check data input \\
$\mathrm{p} 17-\mathrm{t} 15$ & Fill out data output \\
$\mathrm{p} 18$ & End \\
\hline \hline
\end{tabular}

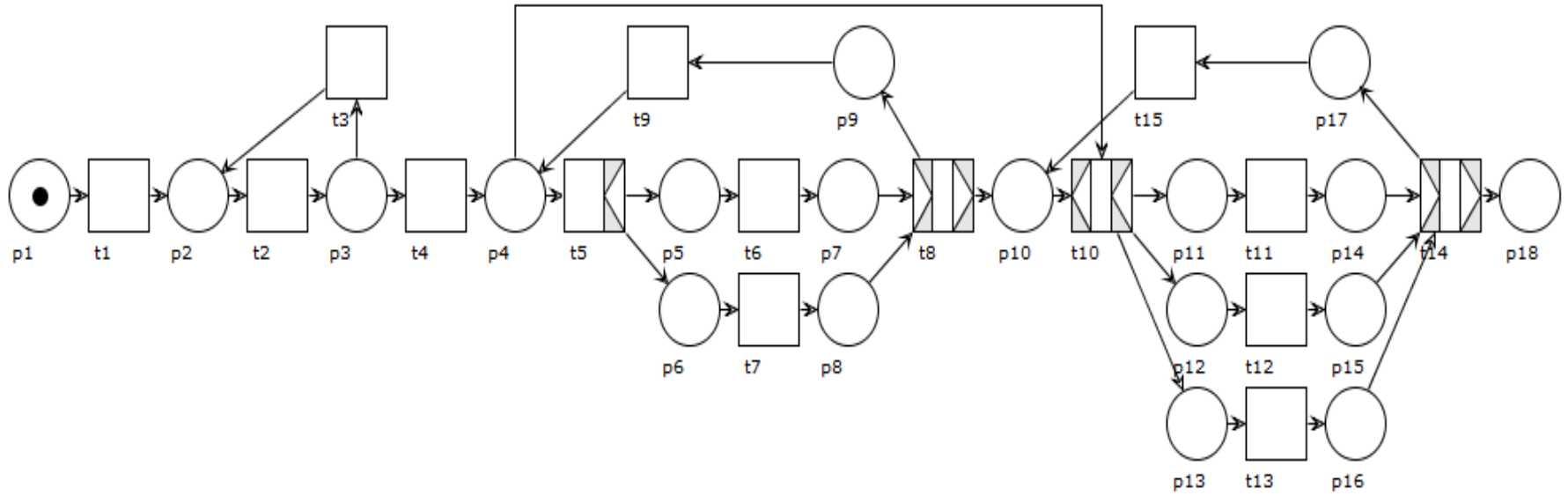

Fig. 1. Petri Net Model for Ijarah Application Sub-Procedure 


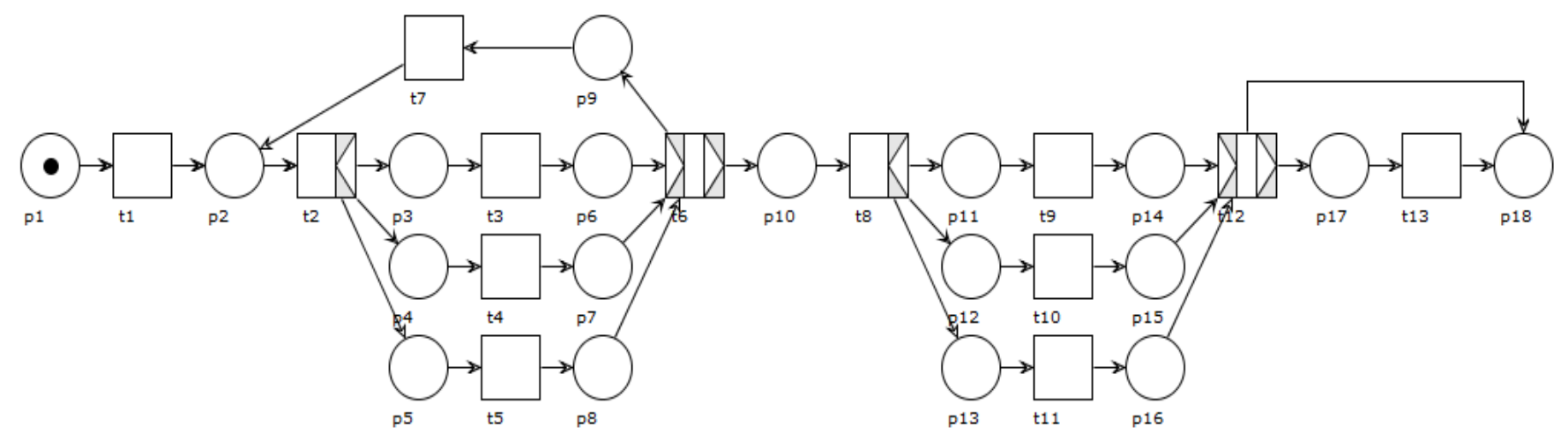

Fig. 2. Petri Net Model for Analysis Sub-Procedure

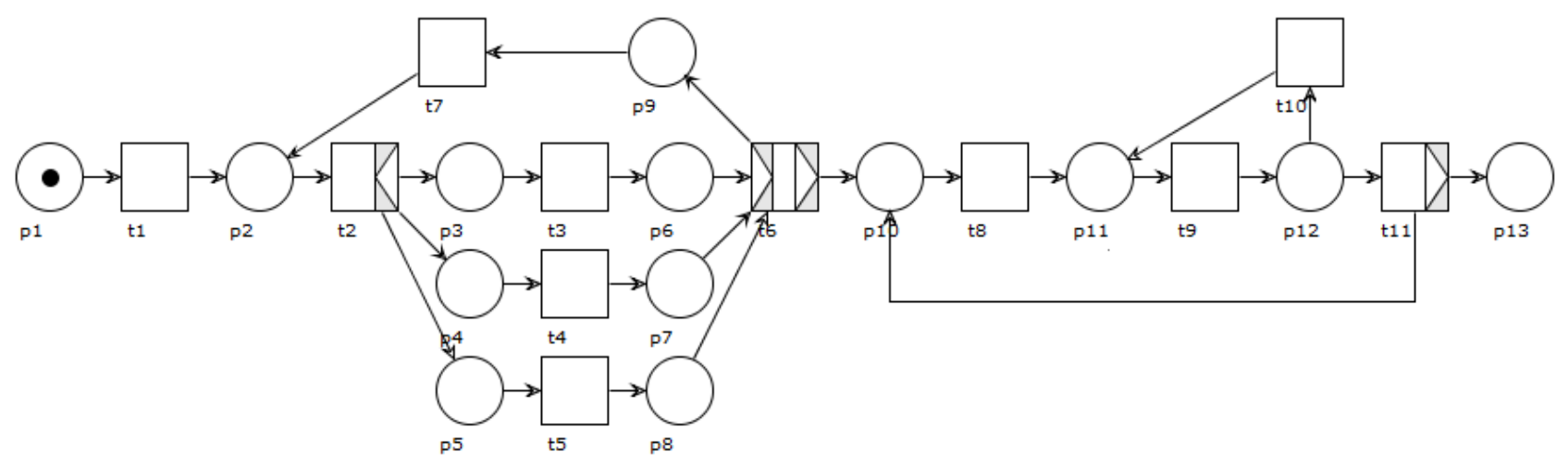

Fig. 3. Petri Net Model for Contract Determination Sub-Procedure

Petri net model for analysis sub-procedure is shown in Fig. 2 where there are 18 places and 13 transitions. Description of the model shown in Table II.

TABLE II

Description of Places and TRANSitions of Petri Net Fig. 2

\begin{tabular}{ll}
\hline \hline Caption & Description \\
\hline p1-t1 & Survey the condition of the debtor \\
p2-t2 & Fill survey result forms \\
p3-t3 & Fill risk identification form \\
p4-t4 & Fill analysis of revenue and cost form \\
p5-t5 & Fill questionnaire \\
p6-t6, p7-t6, p8-t6 & Check data input \\
p9-t7 & Fill out data input \\
p10-t8 & Check survey result \\
p11-t9 & Calculate the value of the questionnaire \\
p12-t10 & Calculate the value of the collateral \\
p13-t11 & Calculate the installments ability \\
p14-t12 & Questionnaires value \\
p15-t12 & Collaterals value \\
p16-t12 & Installments ability \\
t12 & Check analysis result \\
p17-t13 & Determine the realizable value \\
p18 & End \\
\hline \hline
\end{tabular}

Petri net model for contract determination sub-procedure is shown in Fig. 3 where there are 13 places and 11 transitions. Description of the model shown in Table III.

TABLE III

DESCRIPTION OF Places AND TRANSITIONS OF PETRi Net Fig. 3

\begin{tabular}{ll}
\hline \hline Caption & Description \\
\hline p1-t1 & Prepare contract form \\
p2-t2 & Fill contract forms \\
p3-t3 & Fill preamble form \\
p4-t4 & Fill clause 1-4 form \\
p5-t5 & Fill clause 6-9 form \\
p6-t6, p7-t6, p8-t6 & Check data input \\
p9-t7 & Fill out data input \\
p10-t8 & Fill clause 5 form \\
p11-t9 & Check data input \\
p12-t10 & Fill out data input \\
p12-t11 & Check collateral addition \\
p13 & End \\
\hline \hline
\end{tabular}

Fig. 4 shows Petri net model for disbursement sub-procedure. 


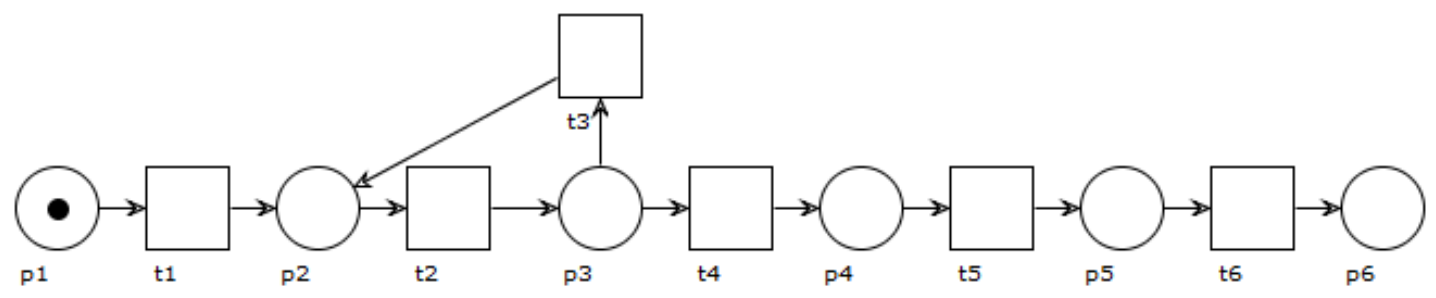

Fig. 4. Petri Net Model for Disbursement Sub-Procedure

In the Petri net model for disbursement sub-procedure as shown in Fig. 4, there are 6 places and 6 transitions. Description of the model shown in Table IV.

TABLE IV

Description of Places AND TRANSITIONS OF PetRi Net Fig. 4

\begin{tabular}{ll}
\hline \hline Caption & Description \\
\hline p1-t1 & Fill disbursement form \\
p2-t2 & Check data input \\
p3-t3 & Fill out data input \\
p3-t4 & Approve the disbursement form \\
p4-t5 & Prepare money \\
p5-t6 & Receive money \\
p6 & End \\
\hline \hline
\end{tabular}

Fig. 5 shows Petri net model for installment sub-procedure.

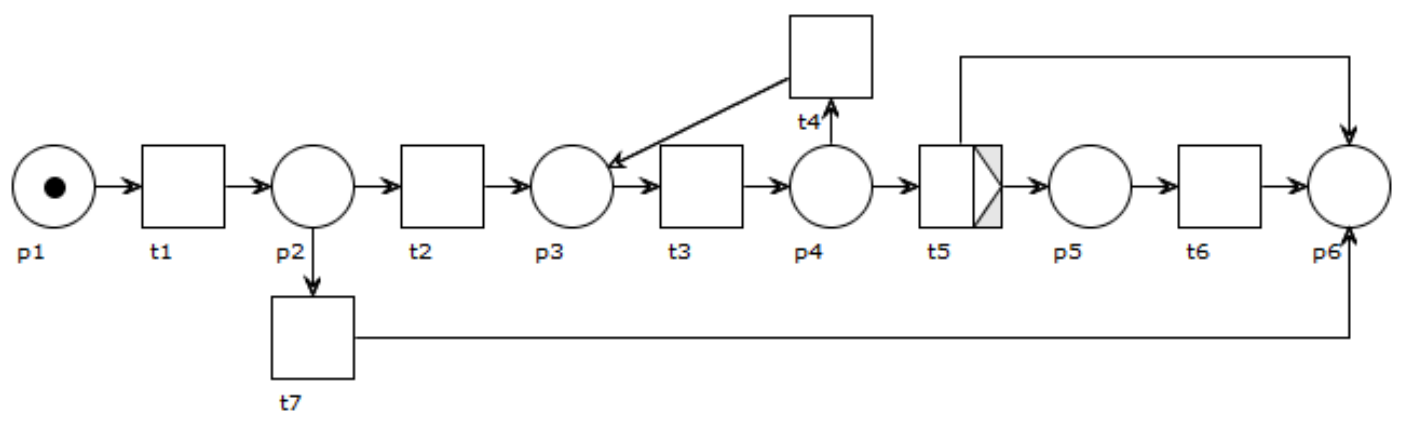

Fig.5. Petri Net Model for Installment Sub-Procedure

In the Petri net model for installment sub-procedure as shown in Fig. 5, there are 6 places and 7 transitions. Description of the model shown in Table V.

TABLE V

DESCRIPTION OF Places AND TRANSITIONS OF PETRI NET FIG. 5

\begin{tabular}{ll}
\hline \hline Caption & Description \\
\hline $\mathrm{p} 1-\mathrm{t} 1$ & Check installments record of customer \\
$\mathrm{p} 2-\mathrm{t} 2$ & Fill cash inflows form \\
$\mathrm{p} 3-\mathrm{t} 3$ & Check data input \\
$\mathrm{p} 4-\mathrm{t} 4$ & Fill out data input \\
$\mathrm{p} 4-\mathrm{t} 5$ & Check installments \\
$\mathrm{p} 5-\mathrm{t} 6$ & Add fines and/or billing charges \\
$\mathrm{p} 2-\mathrm{t} 7$ & Add customer to "deletion of collateral" program \\
$\mathrm{p} 8$ & End \\
\hline \hline
\end{tabular}

Fig. 6 shows Petri net model for settlement sub-procedure. 


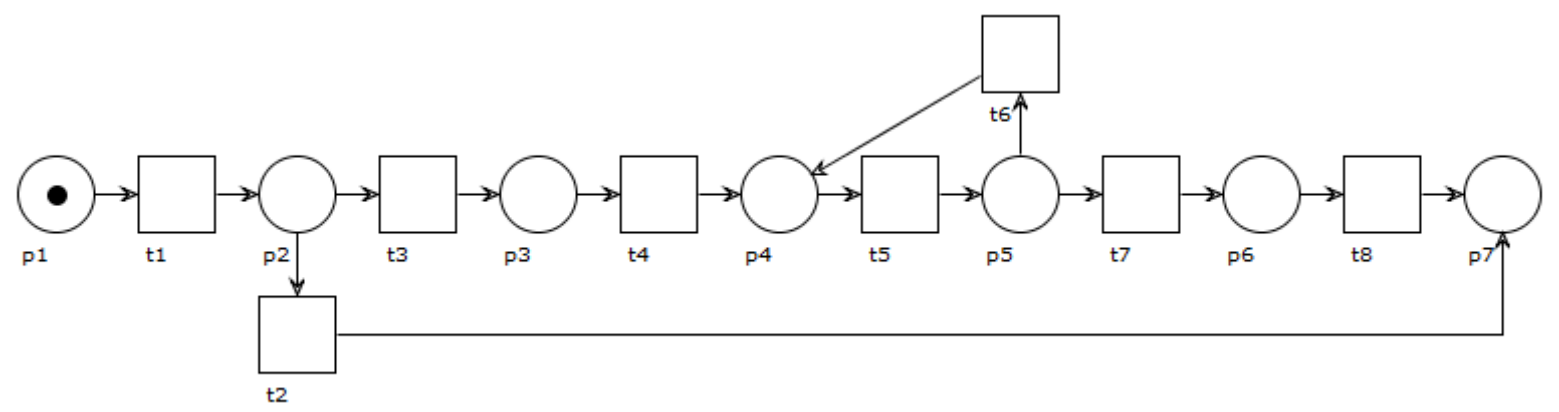

Fig. 6. Petri Net Model for Settlement Sub-Procedure

In the Petri net model for settlement sub-procedure as shown in Fig. 6, there are 7 places and 8 transitions. Description of the model shown in Table VI.

\section{TABLE VI}

Description of Places AND TRANSitions of Petri Net Fig. 6

\begin{tabular}{ll}
\hline \hline Caption & Description \\
\hline p1-t1 & Check installments record of customer \\
p2-t2 & Pay installments \\
p2-t3 & Prepare collateral returns form \\
p3-t4 & Fill collateral returns form \\
p4-t5 & Check data input \\
p5-t6 & Fill out data input \\
p5-t7 & Return the collateral \\
p6-t8 & Receive the collateral \\
p7 & End \\
\hline \hline
\end{tabular}

\section{Petri Net Model Validation}

Validation of the model automatically was done using semantical analysis in editor Woped. All the Petri net models constructed are already free from deadlock and livelock, and meet to the criteria of soundness, liveness, and boundedness.

\section{SimULATION}

The simulation was performed based on the event log on each sub-procedure. In the simulation, there is a date record as the time stamp to record when the process is done.
Table VII shows log event record for application sub-procedure. Event Log shows the process where customer stops at a particular place $p$ and transition $t$ according to the model. Status shows the condition of the customer. Date indicates when the process is done. When the customer log shows p17t15 means customer passes through $t 14$ and stop on p17. Place $p 17$ means the data or files are incomplete. TABLE VII

\begin{tabular}{llll}
\multicolumn{4}{c}{ DESCRIPTION OF PLACES AND TRANSITIONS OF PETRI NET FIG. 6 } \\
\hline \hline id & Log & Status & Date \\
\hline 1 & p18 & Submission succeeded & $10-01-2013$ \\
2 & p18 & Submission succeeded & $12-01-2013$ \\
3 & p18 & Submission succeeded & $16-01-2013$ \\
4 & p17t15 & File incomplete & $18-01-2013$ \\
5 & p18 & Submission succeeded & $24-01-2013$ \\
6 & p18 & Submission succeeded & $27-01-2013$ \\
7 & p18 & Submission succeeded & $30-01-2013$ \\
8 & p18 & Submission succeeded & $14-02-2013$ \\
9 & p18 & Submission succeeded & $18-02-2013$ \\
10 & p18 & Submission succeeded & $26-02-2013$ \\
\hline \hline
\end{tabular}

Log event records each customer can be shown by incidence matrix. Each customer that applying for ijarah can have different incidence matrix depends on completed task. Table VIII shows the incidence matrix of ijarah application sub-procedure for successful application sub-process :

TABLE VIII

INCIDENCE MATRIX OF LOAN APPLICATION MODEL

\begin{tabular}{l|ccccccccccccccc} 
& $\mathrm{t} 1$ & $\mathrm{t} 2$ & $\mathrm{t} 3$ & $\mathrm{t} 4$ & $\mathrm{t} 5$ & $\mathrm{t} 6$ & $\mathrm{t} 7$ & $\mathrm{t} 8$ & $\mathrm{t} 9$ & $\mathrm{t} 10$ & $\mathrm{t} 11$ & $\mathrm{t} 12$ & $\mathrm{t} 13$ & $\mathrm{t} 14$ & $\mathrm{t} 15$ \\
\hline $\mathrm{p} 1$ & -1 & 0 & 0 & 0 & 0 & 0 & 0 & 0 & 0 & 0 & 0 & 0 & 0 & 0 & 0 \\
p2 & 1 & -1 & 1 & 0 & 0 & 0 & 0 & 0 & 0 & 0 & 0 & 0 & 0 & 0 & 0 \\
p3 & 0 & 1 & -1 & -1 & 0 & 0 & 0 & 0 & 0 & 0 & 0 & 0 & 0 & 0 & 0 \\
p4 & 0 & 0 & 0 & 1 & -1 & 0 & 0 & 0 & 1 & 0 & 0 & 0 & 0 & 0 & 0 \\
p5 & 0 & 0 & 0 & 0 & 1 & -1 & 0 & 0 & 0 & 0 & 0 & 0 & 0 & 0 & 0 \\
p6 & 0 & 0 & 0 & 0 & 1 & 0 & -1 & 0 & 0 & 0 & 0 & 0 & 0 & 0 & 0 \\
p7 & 0 & 0 & 0 & 0 & 0 & 1 & 0 & -1 & 0 & 0 & 0 & 0 & 0 & 0 & 0 \\
p8 & 0 & 0 & 0 & 0 & 0 & 0 & 1 & -1 & 0 & 0 & 0 & 0 & 0 & 0 & 0 \\
p9 & 0 & 0 & 0 & 0 & 0 & 0 & 0 & 1 & -1 & 0 & 0 & 0 & 0 & 0 & 0 \\
p10 & 0 & 0 & 0 & 0 & 0 & 0 & 0 & 1 & 0 & -1 & 0 & 0 & 0 & 0 & 1 \\
p11 & 0 & 0 & 0 & 0 & 0 & 0 & 0 & 0 & 0 & 1 & -1 & 0 & 0 & 0 & 0 \\
p12 & 0 & 0 & 0 & 0 & 0 & 0 & 0 & 0 & 0 & 1 & 0 & -1 & 0 & 0 & 0 \\
p13 & 0 & 0 & 0 & 0 & 0 & 0 & 0 & 0 & 0 & 1 & 0 & 0 & -1 & 0 & 0 \\
p14 & 0 & 0 & 0 & 0 & 0 & 0 & 0 & 0 & 0 & 0 & 1 & 0 & 0 & -1 & 0 \\
p15 & 0 & 0 & 0 & 0 & 0 & 0 & 0 & 0 & 0 & 0 & 0 & 1 & 0 & -1 & 0 \\
p16 & 0 & 0 & 0 & 0 & 0 & 0 & 0 & 0 & 0 & 0 & 0 & 0 & 1 & -1 & 0 \\
p17 & 0 & 0 & 0 & 0 & 0 & 0 & 0 & 0 & 0 & 0 & 0 & 0 & 0 & 1 \\
p18 & 0 & 0 & 0 & 0 & 0 & 0 & 0 & 0 & 0 & 0 & 0 & 0 & 0 & 1 & 0
\end{tabular}


In Table VIII, value element -1 indicates the token moves from place towards transition. For example matrix $p 3-t 3$ and p3-t4 has value -1 , which means the token is at $\mathrm{p} 3$ and can perform activities in $t 3$ and $t 4$. Value 1 indicates the token moves from transition towards place. For example matrix $p 4-t 4$ has value 1 , which means after doing activities in $t 4$ token will be heading towards $p 4$. The matrix is 0 means there is no activities between place and the transition concerned. The matrix is 0 on a -1 matrix means the task concerned is not done by the customer.

From 100 tested random data, there are 76 customers passed the application stage, 38 customers passed the analysis stage, 26 customers passed the contract determination stage and disbursement stage, 5 customers experiencing repayment issues, and 1 customer still be in installment processes.

\section{CONCLUSION}

It was shown that Petri net models for ijarah procedure modeling in KSPPS BMT BIMA which consisted of Petri net model for application sub-procedure, analysis sub-procedure, contract determination sub-procedure, disbursement sub-procedure, installment sub-procedure, and settlement sub-procedure. The six models are already free from deadlock and livelock and meet the criteria of soundness, liveness, and boundedness. Application for ijarah simulation has been developed using PHP Programming and it can record the event $\log$ according to the position of the place and the transitions of each customer.

For further research, it may be added other analysis methods such as by applying fuzzy model on ijarah analysis phase.

\section{REFERENCES}

[1] ------------. "Perubahan Undang-Undang Nomor 7 Tahun 1992 Tentang Perbankan". Undang-Undang RI No. 10 Tahun 1998.

[2] Setiawati, M. S., "Pengaruh Giro Wajib Minimum, Ijarah to Deposit Ratio dan Capital Adequacy Ratio Terhadap Jumlah Penyaluran Kredit Pada Bank Pemerintah Periode 2008-2010”, SKRIPSI Jurusan Ekonomi Pembangunan-Fakultas Ekonomi UM, 2012.

[3] Yani, Y., "Evaluasi Pengendalian Internal Terhadap Prosedur dan Kebijakan Pemberian Kredit Usaha Kecil Menengah (UKM) (Studi Kasus Pada PT. Bank Mega, Tbk Cabang Pluit)", Skripsi Fakultas Ekonomi Universitas Esa Unggul, 2013.

[4] Putra, D. A., "Evaluasi Sistem Pemberian Kredit Pada BPR Artha Huda Abadi Kabupaten Pati", Laporan Tugas Akhir UNS-F. Ekonomi dan Bisnis Prog. DIII Akuntansi, 2015.

[5] Majelis Ulama Indonesia, "Pembiayaan Ijarah", Fatwa Dewan Syari'ah Nasional No. 09/DSN-MUI/IV/2000, 2000.

[6] Majelis Ulama Indonesia, "Pembiayaan Multijasa", Fatwa Dewan Syari'ah Nasional No. 44/ DSN-MUI/VIII/2004, 2004

[7] Sanjoyo, B. A., \& Sarno, R, "Pemodelan Komposisi Web Service Dengan Menggunakan Petri Net". Matematika dan Pedidikan Karakter dalam Pembelajaran, 2011.

[8] Van Der Aalst, Wil MP. "Workflow verification: Finding control-flow errors using petri-net-based techniques." Business Process Management. Springer Berlin Heidelberg, 161-183, 2000.

[9] Murata, Tadao. "Petri nets: Properties, analysis and applications." Proceedings of the IEEE 77(4): 541-580, 1989. https://doi.org/10.1109/5.24143

[10] Halder, Abhishek. (August 2006). Submitted in the requirement for the partial fulfillment of Dual Degree in Aerospace Engineering. Department of Aerospace Engineering Indian Institute of Technology Kharagpur. Available: http://people.tamu.edu/ ahalder/PetriNetReport.pdf



Sarngadi Palgunadi Yohanes, He is now a lecture at Informatics Departement, FMIPA University of Sebelas Maret Surakarta and the head of Software Design and Computation Research Group. The research areas conducted are in process mining, algorithms for VRP and job-shop schedulling problem, and optimization problem.

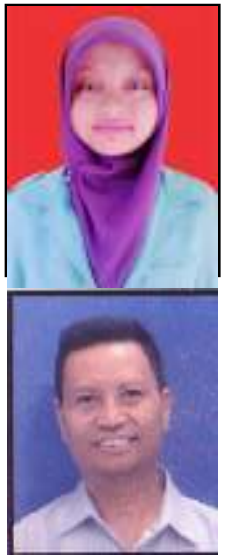

Dania Faaskarini, She is now a student at Informatics Departement, FMIPA University of Sebelas Maret Surakarta. 